\title{
Pedestrian ways arrangement to support the green campus idea: lesson from UNDIP Tembalang campus
}

\author{
Nararya Adi Prasetya ${ }^{1,4^{*}}, P$.Purwanto ${ }^{1,2}$, and Maryono Maryono ${ }^{3,4}$ \\ ${ }^{1}$ Master Program of Environmental Science, School of Postgraduate Studies, Diponegoro University, \\ Semarang - Indonesia \\ ${ }^{2}$ Department of Chemical Engineering, Faculty of Engineering, Diponegoro University, Semarang - \\ Indonesia \\ ${ }^{3}$ Department of Urban and Regional Planning, Faculty Engineering, Diponegoro University, \\ Semarang - Indonesia \\ ${ }^{4}$ Centre for Green Infrastructure Resilience and Development, School of Postgraduate, Diponegoro \\ University, Indonesia
}

\begin{abstract}
Providing more space for non -motorized transportation will change the orientation of how people use the road. The first step of changing the orientation of city development which is car-oriented to people-oriented is how to look at the overall existing road users. Accessibility is the basic part of how an area develops, including on a university development. UI Greenmetric as a parameter of university achieving how it can be called a green campus. Not only designing a good campus, but the 'sustainable' policy also cannot be separated from creating a comfortable environment. The current condition of Diponegoro University's open green space reaches less than $60 \%$, while Undip Tembalang already has a pedestrian lane, but is not utilized properly. The research method uses descriptive analysis of the literature articles on how important the pedestrian path that has been done at other universities. The results show that improving and changing the road design effect. Relating to the comfort of people walk affects how the pedestrian path had used. The official regulations from the university also have an impact on reducing the use of motorized vehicles. Improving accessibility for students to use public transportation and non-motorized transportation could reduce emissions in the campus's environment.
\end{abstract}

Keywords: pedestrian ways, green campus, diponegoro university

*Corresponding author: nararyaadi@students.undip.ac.id 


\section{Introduction}

Sustainable development becomes an interesting topic throughout the world, including in the mid-90s era, the campuses included 'sustainability' in their program and strategic policy planning, by providing a variety of resources developed for the academic community [1]. Not only designing a good campus, but also a 'sustainable' policy cannot be separated from creating a comfortable environment, such as providing space for rest, play and refreshing/recharging [2]. Comfort is important [3], considering that students spend most of their time on campus. If a campus has a population resembling 'which forms a small city [4, 5], the green space and open space becomes an important aspect because of comfort factor [6] related to those two things, density and area [4, 7]. Green spaces on campus and universities have many benefits for students, and the community. Greening large-scale campus also contributes solutions to global environmental problems [8,9]. Diponegoro University (UNDIP) is one of the biggest educational entities in Central Java. UNDIP also known as notable university in Semarang which become one of city icons for education. It has two main campuses located in Semarang city center (UNDIP Pleburan Campus) and in the Semarang southern hilly area (UNDIP Tembalang Campus). UNDIP were mainly located in Pleburan Campus and laid in $87.552 \mathrm{~m}^{2}$ land, but since 2009 the main campus has officially moved to Tembalang Campus which are 15 times more spacious than it was in Pleburan. Laying in 1.729.854 $\mathrm{m}^{2}$ land, UNDIP Tembalang campus continue to develop with various buildings and facilities.In 2019, UNDIP were nominated as the forth "greenest campus" in Indonesia by UI Greenmetric. As one of the eco-friendly campuses, UNDIP continue to innovate in the green activities. It was inevitable that various faculties with diverse activities have become a new center of growth in the Tembalang region. Hence, the development of UNDIP Tembalang Campus more or less will affect the growth of Tembalang Region. Therefore, UNDIP keep on the track as eco-friendly campus with four development orientation for Tembalang campus which are a) Academic Multidisciplinary Studies and Research, b) Science and Techno Park, c) Green and Sustainable, and d) Living-Learning Community (Board of Trustees' Undip Number 7 Year 2016 about Diponegoro University General Policy 2015-2039 in article 12). Actually, since the beginning of the UNDIP main campus in Tembalang, the orientation of its development refers to these four criteria, but its trustee assembly regulation emphasizes more on priorities for the Green and Sustainable scheme on the main campus in Tembalang. One of factors that indicates the successful implementation of green campus is seen by its accessibility including the facility for pedestrian [10] Pedestrian facilities such as pedestrian ways are important to support the implementation of green activities around and inside/outside campus, and to reduce dependence on motorized transportation, which has an impact on reducing the level of pollution in the campus area $[9,11,12,13]$. However, there are still some challenges in implementing the pedestrian friendly ways especially in UNDIP Tembalang campus which are located in hilly area. For further development, initial research is necessary in order to understand the existing condition of pedestrian ways in UNDIP Tembalang campus. Hence, this paper aims to elaborate the existing condition of pedestrian ways in UNDIP Tembalang campus. With better initial observation in 
developing the pedestrian ways in UNDIP Tembalang Campus, recommendation can be applied to make more effective and efficient development in the future.

\section{Methodology}

\subsection{Study Area}

The study area of this research is in Diponegoro University (UNDIP), Tembalang Campus. UNDIP Tembalang campus located in the southern part of Semarang area located approximately $11 \mathrm{~km}$ from Simpang Lima Semarang (city center). As we know, Semarang is famous with having two types of geographical characteristics which are low land (coastal area) in the northern part and hilly area in the southern part. This area of UNDIP Tembalang Campus is included in the Semarang Hilly area which the location is mountainous. As an educational area, Tembalang, where laid the UNDIP Campus, has become the new city center in Southern part of Semarang.

\subsection{Data Collection and Methods}

The data of this research derived from the direct observation which conducted during Februari-March 2020 in UNDIP Tembalang campus. Spatial data were also used to map the pedestrian ways and descriptive analysis was applied to describes the condition of pedestrian ways around the UNDIP Tembalang campus.

\section{Result and discussion}

\subsection{Pedestrian Ways in UNDIP Tembalang Campus}

UNDIP Tembalang Campus has been being built since 1980s and still developing. Since it first development, UNDIP Tembalang Campus has already prepared with pedestrian ways. Thus, the pedestrian ways become the important aspect to be built along with the road. At least there are four corridors in UNDIP Tembalang Campus that were equipped with pedestrian ways which are (1) Outer ring road, (2) Main corridor, (3) Faculty connector, and (4) Building connector. Each road supported with different types of pedestrian ways according to the type of the road. The types including differentiation of the condition of each pedestrian ways also varies for each type of the road. In this point, the existence of pedestrian ways can be seen as 


\subsubsection{Outer Ring Road Pedestrian Ways}
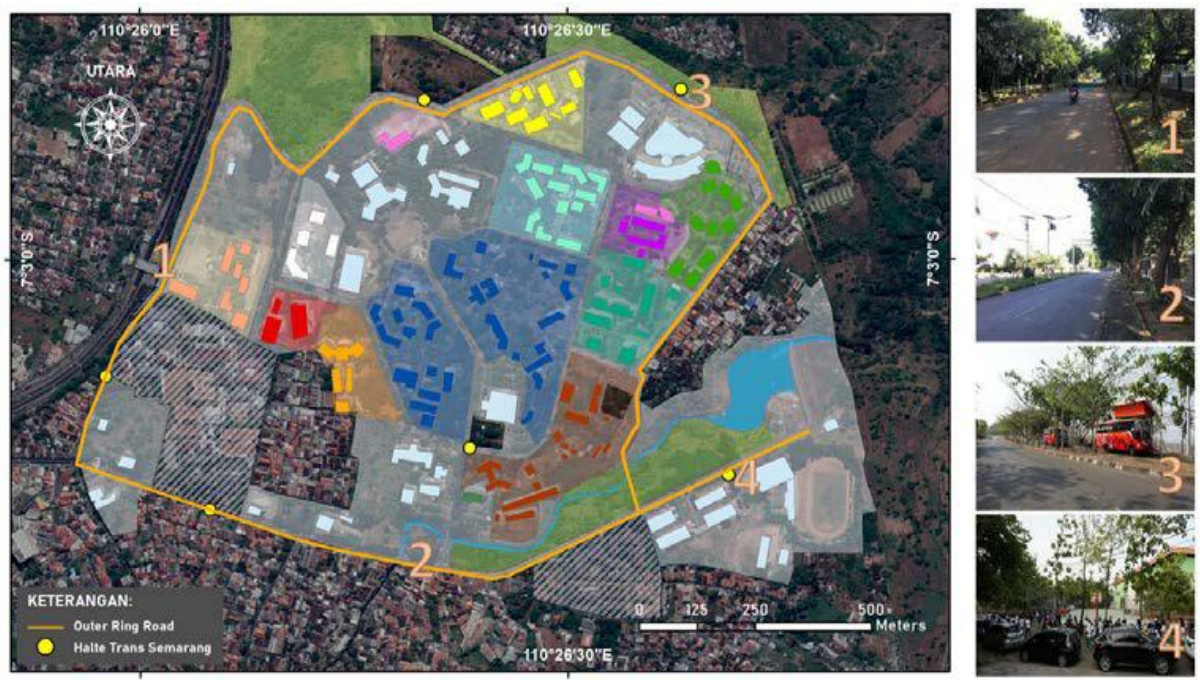

Fig. 1. Road map of Undip Outer Ring Road

The outer ring path is the latest campus facility to connect the area around the campus without the need to connect which is useful to improve internal campus security. This outer ring road is commonly used for Undip residents and access to RSND. Pedestrians can utilize the Trans Semarang shelter which is integrated with the ring road, this outer ring lane is not supported, it has a pedestrian lane. The pedestrian path available in the RSND area is 1.5-2 meters wide, stretching from the faculty of economics to the faculty of agriculture and the Sikatak Bridge.

In addition, the entire ring road has been filled with broad-leafed Ketapang tree vegetation on the right and left side of the road to decrease the heat during the day. The total ring road along $4.76 \mathrm{~km}$, there are $2.55 \mathrm{~km}$ already equipped with pedestrians that form the sidewalk $(53.54 \%)$ 


\subsubsection{Main Road Pedestrian Ways}
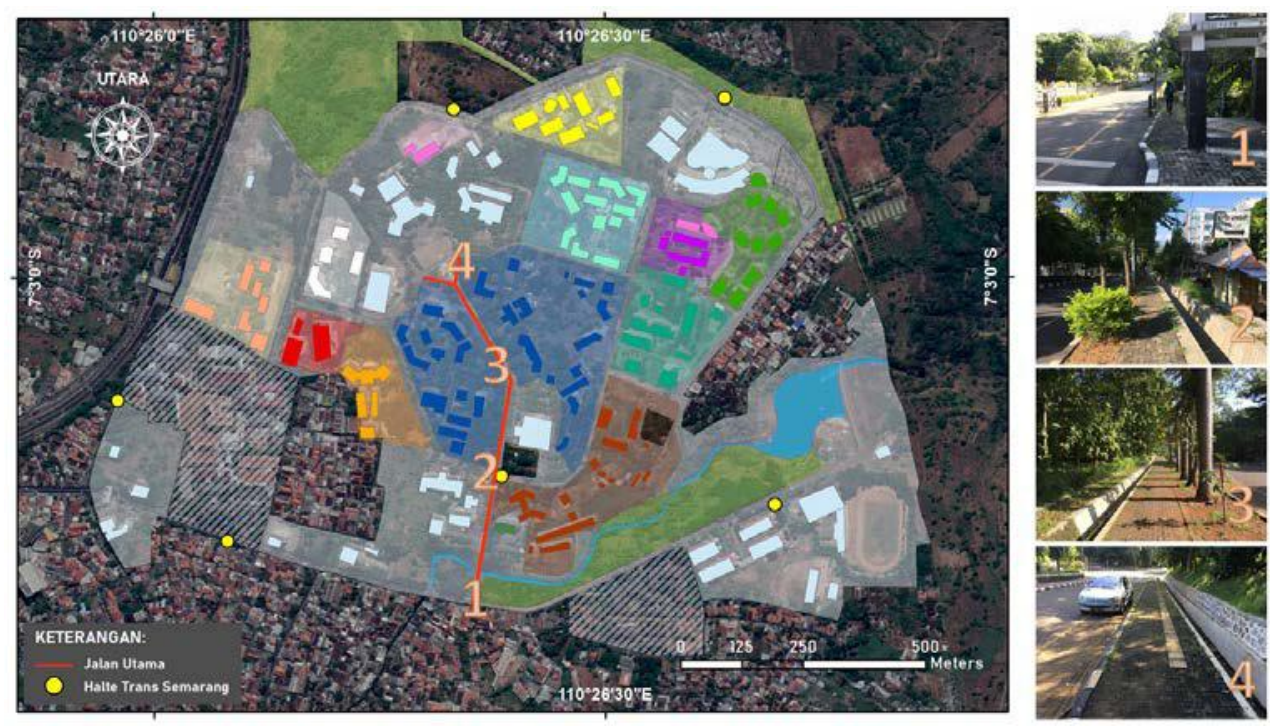

Fig. 2. Undip main road

The main road enters into the campus along 816.14 meters, with a width of 8 meters each for motorized vehicles, and is equipped with pedestrian paths on the sides of the road. In this main lane is equipped with lighting and varied vegetation, namely shade plants and ornamental plants. the width of the pedestrian path is still different on the road, the width is between 1-2 meters. The palem raja is planted on both sides of the road to show the central building of Undip is the rector. This main line service function serves only the office center building and the Faculty of Engineering. 


\subsection{Faculty Connector Pedestrian Ways}
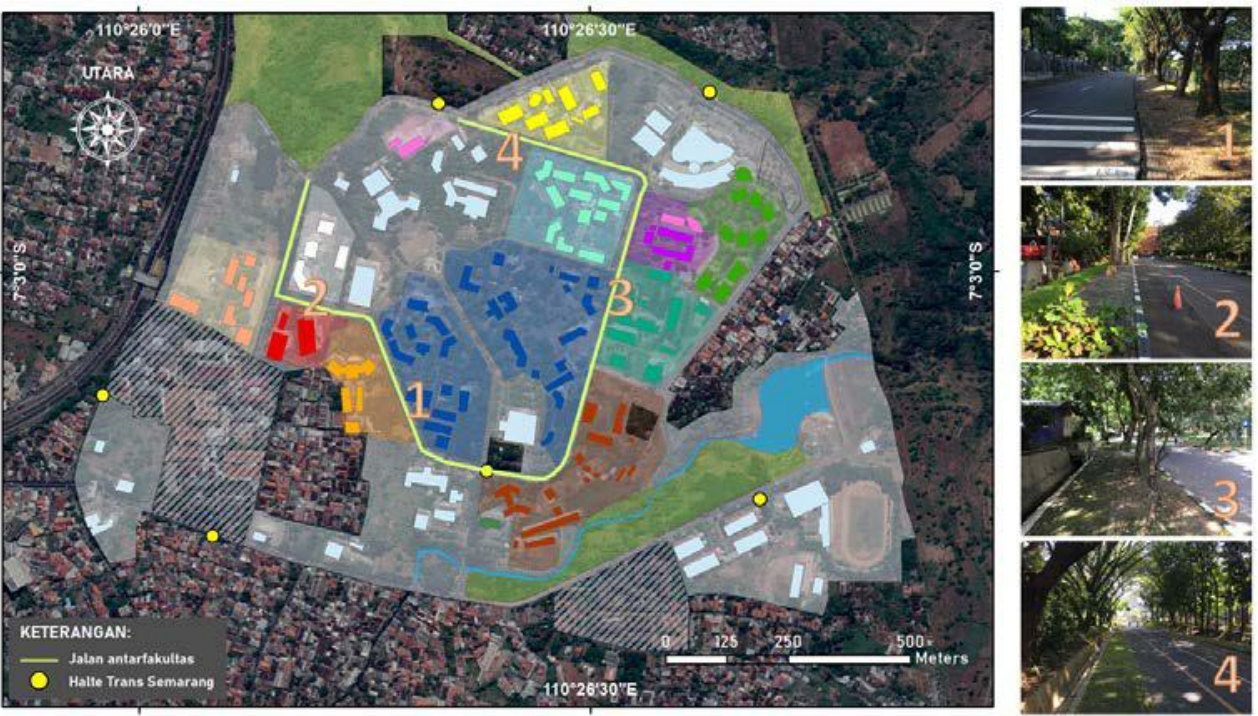

Fig. 3. Undip Faculty Connector

Accessibility between faculties can use this path, the width of the road is 8 meters, equipped with pedestrian facilities with a width of between 1-1.5 meters along with shade vegetation that is located inside the sidewalk, or outside the pedestrian path. With a length of $2.05 \mathrm{~km}$ able to connect each faculty, but not yet fully the connecting road has room to walk. Need to develop pedestrian pathways including seating facilities/park benches for resting pedestrians. The path between faculties needs to be increased in width considering students who need an easy network to socialize.

\subsection{Building Connector Pedestrian Ways}
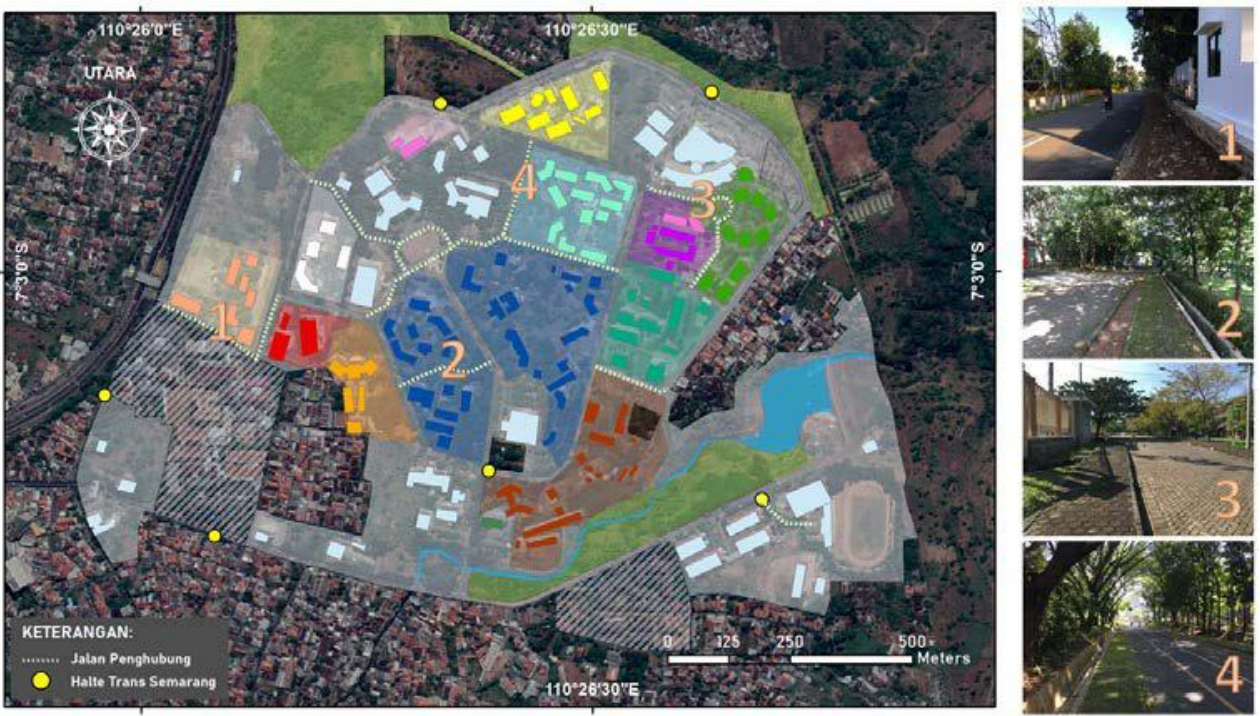

Fig. 4. Undip building connector 
This connecting road facility is used to connect between office and education buildings that are on campus and developed to meet the needs of users around it, has a total length of $2.56 \mathrm{~km}$. shade vegetation follows existing vegetation on the surrounding land use, meaning that no vegetation is designed for pedestrians. The connecting function between buildings with a distance of no more than 500 meters. but facilities for pedestrians still need improvement with facilities for users with special needs.

\section{Conclusion}

Comfort is the main core for people willing to walk, walk freely without obstacles or jeopardizes [3] and it has many benefits from an environmental, [13], economic, and health sector $[12,14,15]$. Actually Undip has considered and planned the pedestrian path since the beginning of the construction. the ring road system to the link between buildings, but in its application in the field, it still does not meet the minimum standards for pedestrian paths, The pedestrian construction still needs a lot of improvement to improve its quality [16]. Undip rank $4^{\text {th }}$ nationally greenest campus by UI Greenmetric, almost every pedestrian path in the Tembalang Undip Campus has shade vegetation, but still need improvement for the pedestrian path in order to make space for pedestrians and campus community because majority of roads on the Tembalang Campus are still car-oriented, considering that sustainable transport (walking) is core from sustainable area $[17,18]$.

\section{Acknowledgement}

The research is funded by Directorate Research and Community Services, Deputy of Research Development, Ministry of Research and Technology / National Research and Innovation Board with cooperation between Institute of Research and Community Services Diponegoro University taskforce letter No. 255-141/UN7.6.1/PP/2020

\section{References}

1. P. Marrone, F. Orsini, F. Asdrubali, and C. Guattari, "Environmental performance of universities: Proposal for implementing campus urban morphology as an evaluation parameter in Green Metric," Sustain. Cities Soc., vol. 42, no. July, pp. 226-239 (2018)

2. G. B. Gulwadi, E. D. Mishchenko, G. Hallowell, S. Alves, and M. Kennedy, "The restorative potential of a university campus: Objective greenness and student perceptions in Turkey and the United States," Landsc. Urban Plan., vol. 187, no. February, pp. 36- 46 (2019)

3. M. V. Corazza, P. Di Mascio, and L. Moretti, "Managing sidewalk pavement maintenance: A case study to increase pedestrian safety," J. Traffic Transp. Eng. (English Ed., vol. 3, no. 3, pp. 203-214 (2016)

4. H. Murwadi and B. Dewancker, "Study of quassessment model for campus pedestrian ways, case study: Sidewalk of the University of Lampung," Sustain., vol. 9, no. 12, pp. 1-16, (2017)

5. Z. Asadi-Shekari, M. Moeinaddini, and M. Zaly Shah, "A pedestrian level of service method for evaluating and promoting walking facilities on campus streets," Land use policy, vol. 38, pp. 175-193 (2014) 
6. Ö. Göçer, K. Göçer, B. Özcan, M. Bakovic, and M. F. Kıraç, "Pedestrian tracking in outdoor spaces of a suburban university campus for the investigation of occupancy patterns,” Sustain. Cities Soc., vol. 45, no. November 2018, pp. 131-142 (2019)

7. S. Shamsuddin, N. R. A. Hassan, and S. F. I. Bilyamin, "Walkable Environment in Increasing the Liveability of a City," Procedia - Soc. Behav. Sci., vol. 50, no. July, pp. $167-178$ (2012)

8. W. Leal Filho, C. Shiel, A. do Paço, and L. Brandli, Putting sustainable development in practice: Campus greening as a tool for institutional sustainability efforts. Elsevier Ltd., (2015)

9. L. Ramakreshnan, N. Aghamohammadi, S. C. Fong, and N. M. Sulaiman, "Motivations and built environment factors associated with campus walkability in the tropical settings," vol. 741, p. 140353 (2020)

10. A. H. Pradana, J. Ernawati, and I. Martiningrum, "Walkability Jalur Pedestrian by Design di Area Kampus Universitas Brawijaya Malang,” (2017)

11. B. Ridhosari and A. Rahman, "Carbon footprint assessment at Universitas Pertamina from the scope of electricity, transportation, and waste generation: Toward a green campus and promotion of environmental sustainability," J. Clean. Prod., vol. 246, p. $119172(2020)$

12. N. Soni and N. Soni, "Benefits of pedestrianization and warrants to pedestrianize an area," Land use policy, vol. 57, no. 5, pp. 139-150, (2016)

13. R. Rafiemanzelat, M. I. Emadi, and A. J. Kamali, "City sustainability: the influence of walkability on built environments," Transp. Res. Procedia, vol. 24, pp. 97-104 (2017)

14. N. Maizlish, N. J. Linesch, and J. Woodcock, "Health and greenhouse gas mitigation benefits of ambitious expansion of cycling, walking, and transit in California," J. Transp. Heal., vol. 6, no. April, pp. 490-500 (2017)

15. K. Nakamura, "The spatial relationship between pedestrian flows and street characteristics around multiple destinations," IATSS Res., vol. 39, no. 2, pp. 156-163 (2016)

16. G. D'Orso and M. Migliore, “A GIS-based method for evaluating the walkability of a pedestrian environment and prioritised investments," J. Transp. Geogr., vol. 82, no. July 2019, p. 102555 (2020)

17. S. C. Addanki and H. Venkataraman, "Greening the economy: A review of urban sustainability measures for developing new cities," Sustain. Cities Soc., vol. 32, pp. 1$8,(2017)$

18. M. Olitsky, Y. Lerman, and E. Avineri, “Analysis of Stated Preferences for Accessible Services and Commerce in a Walkable Distance from Home," Transp. Res. Procedia, vol. 27, pp. 1001-1008 (2017)

19. General Policy Diponegoro University 2015-2039, No.7/2016 